\title{
Perception of the impact of climate change on the quality of life and well-being of the inhabitants of the Cerro Blanco Agricultural Community, Limarí Province, Chile
}

\author{
Percepción del impacto del cambio climático sobre la calidad \\ de vida y el bienestar de los habitantes de la Comunidad Agrícola \\ Cerro Blanco, provincia de Limarí, Chile
}

Andrea A. Alfaro ${ }^{1,2}$, Manuel E. Cortés ${ }^{3,4 *}$

\begin{abstract}
The agricultural communities of the Coquimbo Region (Chile) have centuries-old traditions, which have been threatened by poverty, desertification, and intense droughts for decades and now by climate change. Our aim is to report the perception of the climate change impact on the life quality and well-being of the inhabitants of the Cerro Blanco Agricultural Community in the Limarí province. For this purpose, structured interviews were conducted in this community $(N=22)$. The majority of the interviewees $(n=21 ; 95.45 \%)$ perceived consequences on their quality of life and well-being due to climate change. Regarding the type of consequence, three stand out: effects on physical health $(n=8 ; 36.36 \%)$, on psychological health $(n=5 ; 22.72 \%)$ and on educational and socioeconomic aspects $(n=7 ; 31.81 \%)$. As a conclusion, Cerro Blanco's inhabitants observe the aftermaths of climate change on their quality of life and well-being and these refer mainly to physical and psychological health, and educational and socioeconomic aspects. In the future, we will continue to study this agricultural community so that its inhabitants can achieve greater development, quality of life and well-being, acquire a better relationship with the environment and maintain their centuries-old traditions.

Keywords: drought, human health, poverty, rurality, semi-arid agriculture.
\end{abstract}

\section{RESUMEN}

Desde hace siglos las comunidades agrícolas representan un componente fundamental de la tradición rural de la Región de Coquimbo, Chile. Estas comunidades han sido amenazadas por la pobreza, la desertificación y las intensas sequías durante décadas y, más recientemente, por el cambio climático. Nuestro objetivo es reportar la percepción del impacto de este fenómeno global en la calidad de vida y el bienestar de los habitantes de la Comunidad Agrícola Cerro Blanco de la provincia de Limarí. Para este propósito, se realizaron entrevistas estructuradas $(\mathrm{N}=22)$ en esa comunidad. La mayoría de los entrevistados $(\mathrm{n}=21 ; 95,45 \%)$ percibió consecuencias del cambio climático en su bienestar y calidad de vida. Destacaron especialmente los efectos sobre la salud física $(\mathrm{n}=8 ; 36,36 \%)$, sobre la salud mental $(\mathrm{n}=5 ; 22,72 \%)$ y sobre aspectos educativos y socioeconómicos $(\mathrm{n}=7 ; 31,81 \%)$. Como conclusión, los habitantes de Cerro Blanco perciben consecuencias del cambio climático en su calidad de vida y bienestar que se refieren principalmente a la salud física y mental, y a aspectos educativos y socioeconómicos. En el futuro, continuaremos estudiando esta comunidad agrícola para que sus habitantes puedan lograr un mayor desarrollo, calidad de vida y bienestar, así como una mejor relación con el ambiente y la mantención de sus tradiciones centenarias.

Palabras clave: agricultura semiárida, pobreza, ruralidad, salud humana, sequía.

\footnotetext{
Programa de Doctorado en Educación, Universidad Metropolitana de Ciencias de la Educación, Santiago, Chile.

2 Departamento de Biología, Liceo Experimental Manuel de Salas de la Universidad de Chile, Santiago, Chile.

3 Programa de Magíster en Ciencias Químico Biológicas, Universidad Bernardo O’Higgins, Santiago, Chile.

4 Escuela de Historia y Geografía, Facultad de Educación \& Programa de Doctorado en Educación, Universidad Bernardo O’Higgins, Santiago, Chile.

* Corresponding author: cortesmanuel@docente.ubo.cl
}

Fecha de Recepción: 23 de octubre, 2018.

Fecha de Aceptación: 19 de diciembre, 2019. 


\section{Introduction}

Climate change is a global phenomenon. In Chile, the decrease of rainfall and unusually high temperatures, which cause intense droughts and soil erosion, stands out among the effects associated to climate change (Garreaud, 2010). In particular, agricultural regions located in snowmelt-dominated Mediterranean climate basins are highly vulnerable to this phenomenon (Meza et al., 2012).

International medical organizations have recognized that climate change affects physical and mental health (Watts et al., 2017). How do human beings perceive their health is affected? Perception is the first cognitive process through which the individual obtains information from the environment and allows the subject to form a representation of reality (Sánchez and Barraza, 2015). In the past, human beings identified aspects of the weather and constructed the concept of climate. According to Pinilla et al. (2015) understanding, observing and acting upon climate phenomena has allowed the transformation and maintenance of social practices regarding environmental and productive management over time. In order to establish a relationship between climate change and the perception of quality of life and well-being, it is necessary to define the latter concepts. The World Health Organization (WHO, 1994) defines quality of life as "an individual's perception of his or her position in life in the context of the culture and value system where they live, and in relation to their goals, expectations, standards and concerns. It is a broad ranging concept, incorporating in a complex way a person's physical health, psychological state, level of independence, social relationships, personal beliefs and relationship to salient features in the environment" (WHO, 1994). As for subjective wellbeing, it is a psychological and sociological term that indicates the value that human beings have regarding satisfaction with their life, happiness and their affective capacities (Cuadra and Florenzano, 2003). To the extent that the positive characteristics of these factors exceed the negative ones, we are talking about subjective well-being in the population. Considering this, it is interesting to ask what the perception of the impact of climate change on the quality of life and well-being of rural agricultural communities is.

Therefore, the aim of this work is to report the perception of the climate change impact on the quality of life and well-being of the inhabitants of the Cerro Blanco Agricultural Community in the Limarí province, Chile.

\section{Materials and Methods}

The agricultural community under study is called Cerro Blanco (3052'00.2”S, 71'23'42.8”'W), a rural village with scattered houses located about $50 \mathrm{~km}$ southwest of Ovalle in the Limarí province, Chile (Figure 1A). According to studies of Chilean climatology (Di Castri and Hajek, 1976), its climate could be classified as a semi-arid type, specifically a Mediterranean climate. In this community, there are high temperatures in summer and in winter, a season in which rainfall is concentrated (although it varies considerably from year to year), it is possible to observe fogs, mists and garúas. Springs and wells provide water for irrigation and animal drinking. In several hills, erosive processes are observed (Figure 1A) which have led to the degradation of the soil, the former associated with the decrease of the number of trees and shrubs due to goat overgrazing (Figure 1B) and logging, among other factors (Cortés, 2016; Cortés et al., 2016). The main economic activities are the cultivation of citrus fruits (lemons, key limes and tangerines), activities related to capriculture -sale of artisanal goat cheese, kids and charqui-, and small-scale horticulture (Alfaro et al., 2015; Cortés et al., 2015; Cortés et al., 2017). Finally, it is important to note that in this agricultural community, as well as in nearby localities, the age structure is mainly represented by adults and older adults (Figure 1D), as children and young people migrate to urban centres searching for educational and employment opportunities (Figure 1C and 1D).

During 2018 (summer season), an anonymous structured interview was conducted in members of families who dedicated their work force to agriculture or livestock and who have lived for the last 30 years in the Cerro Blanco Agricultural Community. The interview included a question about the effects of climate change in each of the following dimensions: general physical health, psychological health, economic and labour consequences, and geographic isolation. Three experts reviewed and validated the interview: an inhabitant of the agricultural community, an educational psychologist and an environmental biologist. In addition, in order to adapt the language of the interview to the language of the interviewee and before conducting the interview in 

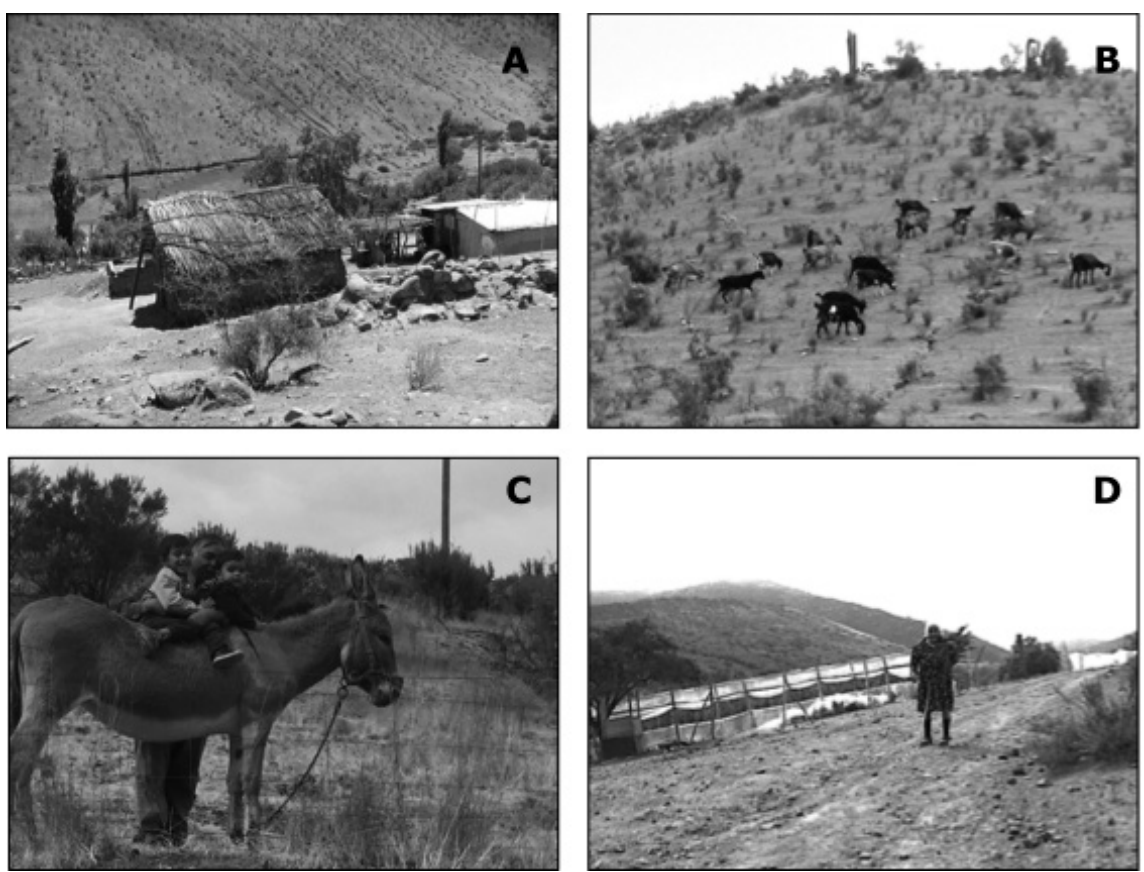

Figure 1. Some characteristics of the Cerro Blanco agricultural community. A. A continuous erosive and desertification process is observed on hillsides, aggravated by droughts and the decrease of water in springs and wells. B. Capriculture is a typical activity, but goat overgrazing has combined its effects with desertification for decades. $\mathbf{C}$. The proportion of children and adolescents living in the community is low and the rural school does not have more than ten students. Moreover, some of these children only travel to the community to visit their grandparents on the weekends. D. The community is inhabited by several elderly adults, which continue to develop a subsistence agro-pastoralism system.

Cerro Blanco, the instrument was tested in Ajial de Quiles, a neighbouring agricultural community with similar characteristics and where several socioenvironmental studies have been previously carried out (Monzó, 2003; Alexander, 2004).

\section{Results and Discussion}

The number of inhabitants that responded to the interview was low $(N=22)$ because few families reside in this agricultural community, and there is a constant process of migration to urban areas as well as aging of the population. The grand majority of the interviewed inhabitants $(n=21 ; 95.45 \%)$ identified consequences of climate change on their health, quality of life and well-being, and in particular, effects on physical health $(n=8 ; 36.36 \%)$, psychological health $(n=5 ; 22.72 \%)$, educational and socioeconomic aspects $(n=7 ; 31.81 \%)$ and also on family distancing $(n=1,4.55 \%)$ (Table 1$)$. However,

Table 1. Consequences of climate change on quality of life and well-being perceived by the inhabitants of Cerro Blanco Agricultural Community $(N=22)$.

\begin{tabular}{|c|c|c|c|c|}
\hline $\begin{array}{l}\text { Are there perceived } \\
\text { consequences? }\end{array}$ & $\begin{array}{c}\text { Proportion of } \\
\text { Consequences }(\%)\end{array}$ & Types of consequence & Inhabitants $(n)$ & $(n / N) \cdot 100(\%)$ \\
\hline \multirow{4}{*}{ Yes } & \multirow{4}{*}{95.45} & Consequences on physical health & 8 & 36.36 \\
\hline & & Consequences on psychological health & 5 & 22.72 \\
\hline & & Educational and socioeconomic consequences & 7 & 31.81 \\
\hline & & Consequences on family distancing & 1 & 4.55 \\
\hline No & 4.55 & There are no consequences & 1 & 4.55 \\
\hline
\end{tabular}


a minor proportion ( $n=1 ; 4.55 \%)$ dismissed effects of climate change on their lives (Table 1).

It is important to highlight that, when conducting the interviews, the inhabitants spontaneously mentioned the association they found between the effects of climate change -degradation of the landscape, disappearance of flora and fauna and decrease of agricultural productivity- and the effects they perceived daily regarding their well-being and quality of life (mainly in terms of their income, health and mood). All of this should be taken into account when applying for development programmes for the Cerro Blanco Agricultural Community, since not focusing on solving these problems can potentiate its effects and risks and add them to the high perception of poverty (20\%) and geographical isolation (60\%) that inhabitants reported in our previous studies (Alfaro et al., 2015).

Climate change affects both the productivity of crops (quantity and quality) and livestock (Jones and Thornton 2003; Altieri and Nicholls, 2009; Rojas-Downing et al., 2018), and it could aggravate the situation of socio-economic vulnerability that some rural agro-pastoralist communities are facing (Monzó, 2003; Fernández and Saunders, 2018), while affecting the physical and mental health of its inhabitants (Cagua, 2017). This, together with the relative geographical isolation that these communities undergo, has an impact on their quality of life and perception of well-being.

In Chile, studies focused on investigating the awareness of well-being and quality of life in the face of climate change are scarce, even less at the level of agricultural communities. However, among them, the work carried out by Infante and Infante (2013) in communities of Yumbel, San Rosendo and Florida (Biobío Region) stands out. These authors report deplorable conditions of natural resources in the rainfed that add to the local effects of global climate change, which are having an impact on the inhabitant's vision of the future, one that is currently very negative (Infante and Infante, 2013). A common strategy has been to migrate to the cities (migration to urban areas that has also been reported in the Cerro Blanco
Agricultural Community (Cortés, 2016; Cortés et al., 2016). However, these researchers highlight a group of families that has been able to innovate and adapt to these new conditions, by using various socioeconomic and agro-ecological strategies to cope with (Infante and Infante, 2013). This adaptation should not only be encouraged, but observed with attention, since it is materialized knowledge and it is put to the test in complex ecological and socioeconomic contexts such as rainfed communities (Infante and Infante, 2013).

We believe that the adaptation of socio-economic and agro-ecological strategies should be replicated in the rural communities of the rainfed area of Region of Coquimbo. Many of the agricultural communities in this region are currently suffering the consequences not only of changing economic factors (Fernández and Saunders, 2018), but also of agro-environmental effects of climate change, plus the consequences that climate change are generating on aspects directly related to human health, such as quality of life and well-being.

\section{Conclusions and future directions}

Regarding the results obtained in this study, it is possible to conclude that the inhabitants of the Cerro Blanco Agricultural Community perceive the consequences of climate change on their quality of life and their well-being. These consequences refer mainly to physical and psychological health and also educational and socioeconomic aspects.

In the future, we will actively continue our investigation, training and advising this agricultural community so that its inhabitants can achieve greater development, quality of life and well-being, acquire a better relationship with the environment and maintain their centuries-old traditions.

\section{Acknowledgements}

The participation of the inhabitants (comuneros) of Cerro Blanco Agricultural Community is deeply appreciated by the authors. M. E. Cortés thanks the support of the XII Concurso de Investigación en Docencia Universitaria UBO. 


\section{Literature Cited}

Alexander, W.L.

2004. Clandestine Artisans or Integrated Producers? Standardization of Rural Livelihood in the Norte Chico, Chile. Culture and Agriculture, 26 (1-2): 38-50.

Alfaro, A.A.; Catalán, M.S.; Cortés, M.E.

2015. Cambio climático, desertificación, pobreza y calidad de vida: el drama de una Comunidad Agrícola de la Provincia del Limarí, Chile. In: Educación Ambiental desde la Innovación, la Transdisciplinariedad e Interculturalidad, Tópicos Selectos de Educación Ambiental. Tepetla, J. \& Pulido, C. (eds.). ECORFAN, Veracruz, México. pp. 116-127.

Altieri, M.; Nicholls, C.

2009. Cambio climático y agricultura campesina: impactos y respuestas adaptativas. LEISA Revista de Agroecología, 24 (4): 5-8.

Cagua, T.A.C.

2017. El cambio climático y sus implicaciones en la salud humana. Ambiente y Desarrollo, 21 (40): 157-171.

Cortés, M.E.; Calderón, F.; Alfaro, A.A.

2017. Emprendimiento e innovación para el producto queso de cabra artesanal de la Región de Coquimbo, Chile: Estado actual y proyecciones futuras. Revista da UIIPS - Unidade de Investigação do Instituto Politécnico de Santarém, 5 (5): 47-53.

Cortés, M.E.

2016. Drought, environmental degradation, work and education: A brief comment on the current reality of agricultural communities in the Limarí Province, Chile. Idesia (Arica), 34 (4): 73-76.

Cortés, M.E.; Alfaro, A.A.; Cavieres, N.P.

2016. Superación de la pobreza en las comunidades agrícolas campesinas de la comuna de Ovalle, Chile: reflexiones desde la educación agroambiental. In: Planificación Territorial, Desarrollo Sustentable y Geodiversidad. Márquez, J.A. (ed.). Servicio de Publicaciones de la Excma. Diputación de Huelva, España. pp. 525, 540-550.

Cortés, M.E.; Catalán, M.S.; Zamorano, S.A.; Alfaro, A.A. 2015. Aspectos sanitarios en la elaboración de quesos de cabra en una comunidad agrícola chilena afectada por la sequía y la desertificación. In: Educación Ambiental desde la Innovación, la Transdisciplinariedad e Interculturalidad, Tópicos Selectos de Educación Ambiental. GonzálezHernández, M. A.; Domínguez-Basurto, M.; García-Durán, A. (eds.). ECORFAN, Veracruz, México. pp. 116-126.

Cuadra, H.; Florenzano, R.

2003. El Bienestar Subjetivo: Hacia una Psicología Positiva. Revista de Psicología de la Universidad de Chile, 12 (1): 83-96.

Di Castri, F.; Hajek, E.R.

1976. Bioclimatología de Chile. Ediciones Universidad Católica de Chile, Santiago, Chile. 128 p.
Fernández, G.L.G.; Saunders, F.

2018. Commoditization of rural lands in the semi-arid region of Chile-the case of the Huentelauquén agricultural community. Agriculture, 8 (2): 26.

Garreaud, R.

2011. Cambio climático: bases físicas e impactos en Chile. Revista Tierra Adentro - INIA, 93: 13-19.

Infante, A.; Infante, F.

2013. Percepciones y estrategias de los campesinos del secano para mitigar el deterioro ambiental y los efectos del cambio climático en Chile. Agroecología, 8 (1): 71-78.

Jones, P.G.; Thornton, P.K.

2003. The potential impacts of climate change in tropical agriculture: the case of maize in Africa and Latin America in 2055. Global Environmental Change, 13: 51-59.

Rojas-Downing, M.M.; Nejadhashemi, A.P.; Harrigan, T.;

Woznicki, S.A.

2018. Climate change and livestock: Impacts, adaptation and mitigation. Climate Risk Management, 16: 145-163.

Meza, F.J.; Wilks, D.S.; Gurovich, L.; Bambach, N.

2012. Impacts of Climate Change on Irrigated Agriculture in the Maipo Basin, Chile: Reliability of Water Rights and Changes in the Demand for Irrigation. Journal of Water Resources Planning and Management, 138 (5): 421-430.

Monzó, E.

2003. Estrategias individuales y colectivas de capital social: el impacto de programas públicos en dos comunidades campesinas. Los casos de Ajial de Quiles y Cerro Blanco, IV Región de Chile. In: Capital Social: Potencialidades Analíticas y Metodológicas para la Superación de la Pobreza. CEPAL - Serie Seminarios y conferencias, $N^{\circ} 31$, United Nations Publications, Santiago, Chile. pp. 243-258.

Pinilla, M.C.; Rueda A.; Pinzón, C.; Sánchez, J.

2012. Percepciones sobre los fenómenos de variabilidad climática y cambio climático entre campesinos del centro de Santander, Colombia. Ambiente y Desarrollo, 16 (31): 25-37.

Sánchez, J.B; Barraza, L.

2015. Percepciones sobre liderazgo. Ra Ximhai - Revista Científica de Sociedad, Cultura y Desarrollo Sostenible, 11 (4): 161-170.

Watts, N.; Adger, W.N.; Ayeb-Karlsson, S.; Bai, Y.; Byass, P.; Campbell-Lendrum, D. Colbourn, T; Cox, P.; Davies, M; Depledge, M.; Depoux, A.

2017. The Lancet Countdown: tracking progress on health and climate change. Lancet, 389 (10074): 1151-1164. WHO.

1994. Statement developed by WHO Quality of Life Working Group. WHO/HPR/HEP/ 98.1, World Health Organization, Geneva, Switzerland. 26 p. 
